\title{
Chemical injury induced by the use of topical imiquimod: case report
}

Lesão química induzida pelo uso de imiquimode tópico: relato de caso

Lesión química inducida por el uso de imiquimodos tópicos: reporte de caso

Anne Diollina Araújo MORAIS

Federal University of Ceará Campus Sobral, UFC - Campus Sobral, 62010-560 Sobral - CE, Brazil https://orcid.org/0000-0002-7208-5520

Gabrielle Oliveira SOUSA

University of Fortaleza, UNIFOR, 60811-905 Fortaleza - CE, Brazil https://orcid.org/0000-0001-9078-0845

Valdelya Nara Pereira AGUIAR

Postgraduate Program, Health Sciences, Federal University of Ceará Campus Sobral, UFC - Campus Sobral, 62042-280 Sobral - CE, Brazil https://orcid.org/0000-0003-0218-6999

Filipe Nobre CHAVES

Postgraduate Program, Health Sciences, Federal University of Ceará Campus Sobral, UFC - Campus Sobral, 62042-280 Sobral - CE, Brazil https://orcid.org/0000-0001-6345-8156

Marcelo Bonifácio da Silva SAMPIERI

Federal University of Ceará Campus Sobral, UFC- Campus Sobral, 62010-560, Sobral - CE, Brazil https://orcid.org/0000-0001-7942-6642

Denise Hélen Imaculada Pereira OLIVEIRA

Postgraduate Program, Health Sciences, Federal University of Ceará Campus Sobral, UFC- Campus Sobral, 62042-280, Sobral - CE, Brazil https://orcid.org/0000-0001-6020-2374

\begin{abstract}
Chemical injury consists in damage caused by a substance when it comes into contact with living tissue. Certain drugs can cause this type of lesion in the oral mucosa. Imiquimod (INN) is an example. Erythema, edema, vesicles, erosions, ulcerations and inflammatory reactions are among the adverse effects associated with the use of INN. Nevertheless, since its effects disappear when terminating treatment, INN is still considered an essential drug in the treatment of condyloma acuminata, actinic cheilitis, superficial basal cell carcinoma and molluscum contagiosum. The objective of this work is to report a clinical case of a 34-year-old male patient presenting a symptomatic lesion on the lower and upper lip mucosa; while including a literature review on potential adverse effects when prescribing topical INN $5 \%$ for the oral mucosa.
\end{abstract}

Descriptors: Pharmaceutical Preparations; Mouth Mucosa; Drug-Related Side Effects and Adverse Reactions.

\section{Resumo}

Introdução: As lesões químicas consistem em alterações causadas por substâncias que causam danos ao entrar em contato com tecidos vivos. Alguns medicamentos podem causar esse tipo de lesões na mucosa oral, sendo o imiquimode (IMI) um exemplo deles. Dentre os efeitos adversos associados ao uso do IMI estão eritema, edema, vesículas, erosões, ulcerações e reações inflamatórias. Apesar disso, o IMI ainda é considerado um poderoso fármaco no tratamento de lesões, como condiloma acuminado, queilite actínica, carcinoma basocelular superficial e molusco contagioso, já que seus efeitos desaparecem ao interromper o tratamento. Objetivo: relatar o caso clínico de um paciente do sexo masculino, de 34 anos de idade, que possuía uma lesão sintomática em mucosa labial inferior e superior; além de fazer uma revisão de literatura sobre os possíveis efeitos adversos do IMI tópico $5 \%$ aplicado em mucosa oral.

Descritores: Preparações Farmacêuticas; Mucosa Bucal; Efeitos Colaterais e Reações Adversas Relacionados a Medicamentos.

\section{Resumen}

Introducción: las lesiones químicas consisten en cambios causados por sustancias que causan daños cuando entran en contacto con tejidos vivos. Algunas drogas pueden causar este tipo de lesión en la mucosa oral, siendo el imiquimod (IMI) un ejemplo de ellas. Entre los efectos adversos asociados con el uso de IMI se encuentran eritema, edema, vesículas, erosiones, ulceraciones y reacciones inflamatorias. A pesar de esto, el IMI todavía se considera un fármaco poderoso en el tratamiento de lesiones, como el condiloma acuminado, la queilitis actínica, el carcinoma basocelular superficial y el molusco contagioso, ya que sus efectos desaparecen cuando se interrumpe el tratamiento. Objetivo: informar el caso clínico de un paciente masculino de 34 años que tenía una lesión sintomática en la mucosa del labio inferior y superior; Además de revisar la literatura sobre los posibles efectos adversos del IMI tópico 5\% aplicado a la mucosa oral.

Descriptores: Preparaciones Farmacéuticas; Mucosa Bucal; Efectos Colaterales y Reacciones Adversas Relacionados con Medicamentos.

\section{INTRODUCTION}

Chemical lesions in the oral mucosa are associated with numerous agents, including medications, non-pharmacological substances, illicit drugs, and dental materials ${ }^{1}$. Such injuries when related to medications can be classified as adverse reactions. Clinically, regardless of the associated aggressor agent, chemical lesions are often similar in appearance; presenting mucosal destruction that ranges from superficial epithelial desquamation to a deeper and more extensive involvement of the epithelium and the underlying submucosal connective tissue ${ }^{1-3}$. A multitude of medications that patients take to control illness can also exposes them to the risk of developing adverse reactions ${ }^{4}$.

$$
\text { Imiquimod (INN) is a topical }
$$

immunomodulatory drug that works by activating the Toll-like receptor-7 (TLR-7), resulting in proinflammatory cytokine and chemokine release, strengthening of the acquired immune system, activation of $\mathrm{T}$ lymphocytes, and other immune responses which help to control intracellular viruses, tumors, and parasites ${ }^{5}$. The US Food and Drug Administration indicates INN for the treatment of warts, superficial and small basal cell carcinomas $(<2 \mathrm{~cm})$, and actinic keratosis to within a contiguous area of $25 \mathrm{~cm}^{2,6}$.

Despite the fact that INN is considered a proven chemotherapy, there are few studies on application in the oral mucosa. The most common adverse effect related to the use of INN in the oral mucosa is local irritation, including 
erythema, ulceration, and pain ${ }^{7,8}$. The aim of this study is to report a clinical case of chemical injury resulting from treatment with topical INN, and perform a literature review on adverse effects involving the oral mucosa. The case report demonstrates the need for medical awareness and clear patient guidance concerning dose limitations when prescribing a specific therapy such as INN.

CLINICAL CASE

A 34-year-old male patient sought clinical care complaining of a symptomatic lesion in the lower and upper labial mucosa with approximately one month of evolution. During the anamnesis, the patient reported that the appearance of the lesion began after applying INN $5 \%$ cream (Aldara) prescribed by a dermatologist as treatment for a white, plaqueshaped, asymptomatic lesion located on the lower lip. The medication was used according to the dermatologist's instructions: applied to the lesion, three times a week. The patient also commented that the lesion symptoms started about 15 days after the first applications, which were continuing. Soon, the symptoms increased to the point of making it difficult to eat, causing weight loss "a few kilos". This motivated him seek care at a stomatology clinic. Clinically, the lesion presented an extensive area of ulceration and erosion which extended throughout the upper and lower labial mucosa with redness of the lower lip (Figure 1A and B).

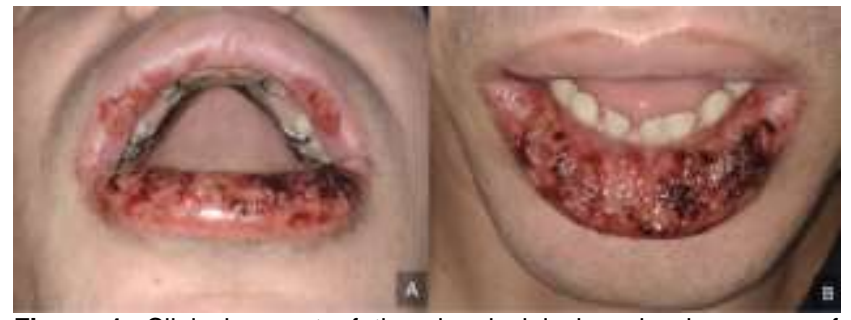

Figure 1. Clinical aspect of the chemical lesion showing areas of Erythema, edema, erosions and ulcerations in (A) Upper lip and (B) Lower lip.

The patient was normal-systemic and presented no other notable changes. In view of what had been reported, with clinical and physical examination, a diagnosis was made of chemical injury induced by the use of topical INN. In the presence of such lesions and the patient's comorbidity, it was decided to request suspension of INN; with prescriptions of oral prednisone (40 mg: one $20 \mathrm{mg}$ tablet every 12 hours for seven days) and topical clobetasol propionate to be applied to the injury three times a day for seven days. At the first follow-up visit, (one week after the initial visit), a significant improvement in the clinical condition was observed. The lesions on the upper lip had healed, and those on the lower lip were beginning the healing process (Figure 2A and $B$ ).

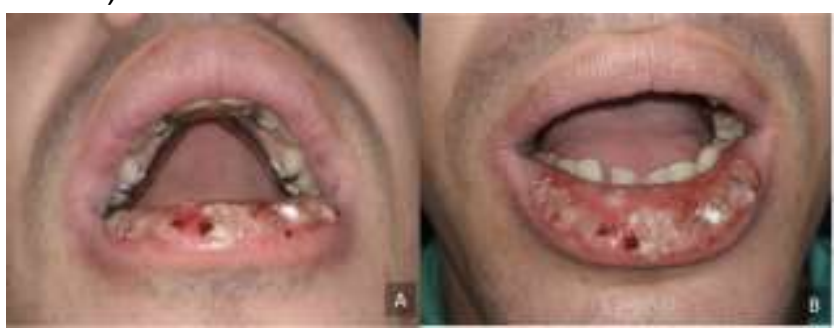

Figure 2. Clinical aspect of the chemical lesion after 1 week of treatment as systemic and topical corticosteroids. (A) Upper lip showing complete resolution; (B) Lower lip in the healing process.

It was decided to decrease the prednisone dosage to $20 \mathrm{mg}$ (one tablet a day, for 7 days) and to continue using topical clobetasol propionate. At the second follow-up visit, (the second week of treatment), the use of systemic corticosteroids was suspended, leaving only topical corticosteroids for another week. The patient presented significant improvement with only a few areas still in the process of healing (Figure 3A). After three weeks of treatment and total resolution of the clinical picture, the treatment was finished and medication was suspended (Figure 3B).

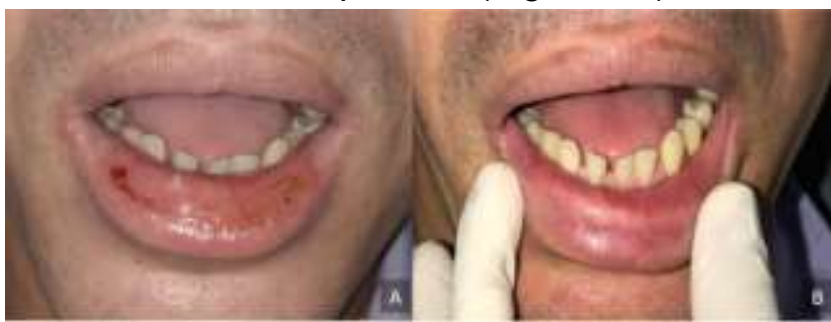

Figura 3. (A) Clinical aspect of the lesion on the lower lip after 2 weeks of treatment with topical corticosteroids and showing the final healing phase. (B) Complete remission of the chemical lesion after 3 weeks of treatment with topical corticosteroids.

DISCUSSION

INN, considered a topical chemotherapy, is an agonist of the TLR-7, and belongs to the imidazoquinolines family which act as immunomodulators ${ }^{8-14}$. INN stimulates an immune response by inducing, synthesizing and releasing monocyte/macrophage-derived cytokines, such as interferon, tumor necrosis factor (TNF), interleukins (IL) IL-1, IL-6, IL-8, and $\mathrm{IL}-12$, as well as prostaglandin E2 and IL-10 (dominant $\mathrm{TH} 1$ cytokine pattern) ${ }^{13}$, acting directly on cellular immunity, through induction of indirect antiviral and anticancer activities $^{10,13-15}$.

INN is marketed as a white or slightly yellowish cream $5 \%$ (Aldara $\AA 3 \mathrm{M}$ ), and is used successfully to treat certain skin pathologies, such as superficial basal cell carcinoma, Bowen's disease, superficial squamous carcinoma, malignant superficial melanomas, actinic keratosis, and genital warts. It is contraindicated in patients with hypersensitivity to INN or to any other component of the 
formula ${ }^{11,16}$. Dosage and method of administration differ according to clinical indication. There is no published pharmacokinetic data on mucosal application of INN and in general, oral application of imiqumod is prohibited ${ }^{17}$. However, intraoral application of INN has been successfully used for oral leukoplakia and intraoral melanoma with no systemic side-effects ${ }^{18}$.

Given local administration, systemic side effects are rare and local reactions are more frequent. These include: edema, itching, burning sensation, bleeding, gallbladder, abrasions, crusts, hardening, tenderness, pain, eczematization, erosion, ulceration and induction of other dermatoses. Also, these effects are usually resolved upon interruption of treatment ${ }^{7,8,10,11,14,19}$. Though only a small amount of the drug is expected to reach systemic circulation, unusual systemic side effects have been reported including: headache, upper respiratory tract infection, gastrointestinal symptoms and certain non-dermatological disorders (neuropathic pain, thyroiditis, abnormal liver function, etc. 7,8,10,11,13-15,19-27

In the present case, the oral mucosa was the only affected site, a chemical lesion that brought a certain comorbidity to the patient, presenting extensive areas of ulceration, erosion, edema and erythema covering the entire length of the lower lip and part of the upper lip; and causing local itching, burning, irritation and pain.

Though INN has already proven its effectiveness, its use in oral mucosa is not considered common ${ }^{28}$. Some case reports in the literature emphasize this potential for adverse effects. Currently, there are some studies reporting adverse effects resulting from the use of INN to treat oral lesions (Table I). Of the reported adverse effects, some presented a higher degree of comorbidity than others. However, due to the small number of cases reported, it is not possible to confirm a direct relationship between the mode of application and the intensity of the adverse reactions.

In the cases reported by Esquivel et al. ${ }^{8}$ and Barikbin et al. ${ }^{7}$, INN was respectively used as a treatment for oral lesions in human papillomavirus (HPV) and multifocal epithelial hyperplasia; the posology consisted of seven applications per week. In these cases, erythema and erosions were predominantly reported. Lesions were located on the gums, tongue, palate, cheek and labial mucosa; the effects coincided with the areas of application.

As reported by Mcdonalds et al. $^{23}$, Chakrabarty et al. ${ }^{10}$ and Gencoglan et al. ${ }^{19}$, in cases using INN to treat actinic cheilitis and lichen planus, undesirable reactions were observed upon five applications, among them, aphthous ulcers, crust, erythema, itching, irritation, burning, and pain. Brown et al. ${ }^{20}$, Chakrabarty et al. ${ }^{10}$ and Ermertcan et al. ${ }^{22}$, in cases of actinic cheilitis and micro-invasive squamous cell carcinoma, (being treated with just two applications of INN per week), ulcers, erythema and irritation were reported as adverse effects.

Table 1. Cases of adverse effects involving the oral mucosa induced by the use of topical INN

\begin{tabular}{|c|c|c|c|c|}
\hline Year & Reference & Oral injury & INN posology $5 \%$ & Adverse reactions \\
\hline 2000 & Rinne et al. & Papilloma & $\begin{array}{c}3 \times \text { a week for } 12 \\
\text { weeks. }\end{array}$ & $\begin{array}{l}\text { Burning and } \\
\text { erythema. }\end{array}$ \\
\hline 2002 & Smith et al. & Actinic cheilitis & $\begin{array}{c}\text { 3x a week for } 4 \\
\text { weeks. }\end{array}$ & $\begin{array}{c}\text { Inflammation in } \\
\text { different degrees of } \\
\text { severity and edema. }\end{array}$ \\
\hline 2003 & $\begin{array}{l}\text { Wenzel et } \\
\text { al. }\end{array}$ & $\begin{array}{c}\text { Oral florid } \\
\text { papilomatosis }\end{array}$ & $\begin{array}{l}3 \mathrm{x} \text { a week for } 4 \\
\text { months ( } 2 \text { weeks } \\
\text { yes, } 2 \text { weeks no). }\end{array}$ & $\begin{array}{l}\text { Severe irritation, } \\
\text { erosion and pain. }\end{array}$ \\
\hline 2005 & $\begin{array}{c}\text { Chakrabart } \\
\text { y et al. }\end{array}$ & Actinic cheilitis & $\begin{array}{l}3 \mathrm{x} \text { a week for } 3 \\
\text { weeks plus } 5 \mathrm{x} \mathrm{a} \\
\text { week for } 1 \text { week. }\end{array}$ & $\begin{array}{c}\text { Edema and aphthous } \\
\text { ulcers. }\end{array}$ \\
\hline 2005 & $\begin{array}{l}\text { Chakrabart } \\
\text { y et al. }\end{array}$ & Actinic cheilitis & $\begin{array}{c}3 \mathrm{x} \text { a week for } 3 \\
\text { weeks. }\end{array}$ & Aphthous ulcers. \\
\hline 2005 & $\begin{array}{l}\text { Chakrabart } \\
\text { y et al. }\end{array}$ & Actinic cheilitis & $\begin{array}{c}2 \mathrm{x} \text { a week for } 5 \\
\text { weeks. }\end{array}$ & Aphthous ulcers. \\
\hline 2009 & Yasar et al. & $\begin{array}{c}\text { Multifocal } \\
\text { epithelial } \\
\text { hyperplasia }\end{array}$ & $\begin{array}{c}\text { 3x a week for } 16 \\
\text { weeks. }\end{array}$ & $\begin{array}{c}\text { Burning, erosion and } \\
\text { headache. }\end{array}$ \\
\hline 2010 & $\begin{array}{l}\text { Mcdonald } \\
\text { et al. }\end{array}$ & Actinic cheilitis & $\begin{array}{c}5 \mathrm{x} \text { a week for } 6 \\
\text { weeks. }\end{array}$ & $\begin{array}{c}\text { Erythema, } \\
\text { ulceration, crust and } \\
\text { pain. }\end{array}$ \\
\hline 2011 & Kwon et al. & $\begin{array}{l}\text { Verrucous } \\
\text { Carcinoma }\end{array}$ & $\begin{array}{c}\text { 3x a week for } 8 \\
\text { weeks. }\end{array}$ & $\begin{array}{l}\text { Erythema, crust with } \\
\text { exudation and pain. }\end{array}$ \\
\hline 2011 & Kwon et al. & $\begin{array}{l}\text { Verrucous } \\
\text { Carcinoma } \\
\end{array}$ & $\begin{array}{c}3 \times \text { a week for } 7 \\
\text { weeks. }\end{array}$ & Erythema and crust. \\
\hline 2011 & $\begin{array}{l}\text { Gencoglan } \\
\text { et al. }\end{array}$ & Lichen planus & $\begin{array}{c}5 \mathrm{x} \text { a week for } 2 \\
\text { weeks }\end{array}$ & $\begin{array}{l}\text { Prominent erosion } \\
\text { and crust. }\end{array}$ \\
\hline 2011 & $\begin{array}{l}\text { Sotiriou et } \\
\text { al. }\end{array}$ & Dysplasia & $\begin{array}{l}\text { 3x a week for } 4 \\
\text { weeks. }\end{array}$ & $\begin{array}{l}\text { Itching, burning, } \\
\text { erythema, edema, } \\
\text { erosions and } \\
\text { ulcerations. }\end{array}$ \\
\hline 2013 & $\begin{array}{l}\text { Emertcan } \\
\text { et al. }\end{array}$ & $\begin{array}{l}\text { Microinvasive } \\
\text { squamous cell } \\
\text { carcinoma }\end{array}$ & $\begin{array}{c}5 \mathrm{x} \text { a week for } 2 \\
\text { weeks. }\end{array}$ & $\begin{array}{l}\text { Burning and } \\
\text { irritation. }\end{array}$ \\
\hline 2014 & $\begin{array}{c}\text { Brown et } \\
\text { al. }\end{array}$ & Actinic cheilitis & $\begin{array}{c}2 \mathrm{x} \text { a week for } 3 \\
\text { weeks. }\end{array}$ & Liqueinoid reaction \\
\hline 2014 & $\begin{array}{l}\text { Barikbin et } \\
\text { al. }\end{array}$ & $\begin{array}{c}\text { Multifocal } \\
\text { epithelial } \\
\text { hyperplasia }\end{array}$ & $\begin{array}{c}7 \mathrm{x} \text { a week for } 16 \\
\text { weeks. }\end{array}$ & $\begin{array}{l}\text { Erythema and } \\
\text { erosion }\end{array}$ \\
\hline 2015 & $\begin{array}{l}\text { Esquivel et } \\
\text { al. }\end{array}$ & Oral HPV lesions & $\begin{array}{c}7 \mathrm{x} \text { a week for } 5 \\
\text { weeks }\end{array}$ & Erosion \\
\hline 2020 & $\begin{array}{l}\text { Present } \\
\text { case }\end{array}$ & Actinic cheilitis & $\begin{array}{c}3 \mathrm{x} \text { a week for } 4 \\
\text { weeks }\end{array}$ & $\begin{array}{l}\text { Itching, burning, } \\
\text { erythema, edema, } \\
\text { erosions and } \\
\text { ulcerations. }\end{array}$ \\
\hline
\end{tabular}

Other reports relate adverse reactions such as aphthous ulcers, erosions, edema, itching, pain, and burning when INN was prescribed at three applications per week, (the therapeutic dosage adopted in the present case) $)^{10,11,13-15,25,26 .}$.

Adverse effects affecting the oral mucosa were more intense following INN treatment of lesions such as actinic cheilitis; other lesions presented milder manifestations. From a universe of 64 cases, 16 presented either moderate or severe reactions, of which 14 were characterized as actinic cheilitis lesion. Thus, the majority of the cases reporting severe adverse reactions in the literature were actinic $^{10,13,20,23}$. According to some authors, serious adverse events are secondary to systemic absorption and are related to the mechanism of action of the drug through activation of pathological cytokines ${ }^{29,30}$. 
In the present case, upon complete resolution of the chemical lesions caused by the use of INN, an incisional biopsy of the initial lesion was realized that confirmed the diagnosis of actinic cheilitis, and also that the use of INN in actinic cheilitis causes more severe adverse manifestations.

In most cases reported in the literature, treatment with INN is interrupted upon facing an adverse reaction. Treatment is thus postponed until the condition improves. In the present case, (where the patient continued to use the INN cream), this did not occur. The existing chemical lesion worsened without improvement in the condition and patient weight loss also resulted for not being able to eat properly.

\section{CONCLUSION}

Thus, we conclude that the topical INN generally presents few local adverse effects. However, in cases of actinic cheilitis it can induce more significant reactions. In the present case and in other similar case reports, the most common local reaction is characterized as chemical injury induced by the use of a specific medication.

\section{REFERENCES}

1. Gilvetti C, Porter SR, Fedele S. Traumatic chemical oral ulceration: a case report and review of the literature. $\mathrm{Br}$ Dent J. 2010; 208:297-300.

2. Dayakar MM, Pai PG, Madhavan SS. "Tetracycline hydrochloride chemical burn" as self-inflicted mucogingival injury: A rare case report. Indian J Dermatol Venereol Lepro. 2012; 16:282-85.

3. Vargo RJ, Warner BM, Potluri A, Prasad JL. Garlic burn of the oral mucosa: A case report and review of self-treatment chemical burns. J Am Dent Assoc. 2017;767-71.

4. Yuan A, Woo SB. Adverse drug events in the oral cavity. Oral Surg Oral Med Oral Pathol Oral Radiol. 2015;119:35-47.

5. Stanley MA. Imiquimod and the imidazoquinolones: mechanism of action and therapeutic potential. Clin Exp Dermatol. 2002; 27:571-77.

6. Sapijaszko MJ. Imiquimod $5 \%$ cream (Aldara) in the treatment of basal cell carcinoma. Skin Therapy Lett. 2005;10:2-5.

7. Barikbin B, Tehranchinia Z, Mozafari N. Treatment of multifocal epithelial hyperplasia with imiquimod. Indian J Dermatol Venereol Leprol. 2014;80:175-77.

8. Esquivel LP, Fernández LC, Saeb ML, Guerrero BAR, Hernández AS, Méndez SF. Recalcitrant oral squamous cell papilloma lesions in two HIV-infected patients successfully treated with topical imiquimod. J Dermatol Case Rep. 2015;9:19-22.
9. Chan MYL, Kennedy J, Oakley A. Erythema multiforme triggered by imiquimod $5 \%$ cream. Australas J Dermatol. 2017;58:257-58.

10. Chakrabarty AK, Mraz S, Geisse JK, Anderson NJ. Aphthous ulcers associated with imiquimod and the treatment of actinic cheilitis. J Am Acad Dermatol. 2005;52:35-7.

11. Kwon HB, Choi YS, Lee JH, Jin SY, Kim BJ, Lee $\mathrm{SH}$ et al. Treatment of verrucous carcinoma of the lower lip with topical imiquimod (Aldara $\AA$ ) and debulking therapy. Ann Dermatol. 2011;23:68-71.

12. Salgueiro AP, de Jesus LH, de Souza IF, Rados PV, Visioli F. Treatment of actinic cheilitis: a systematic review. Clin Oral Investig. 2019;23:2041-53.

13. Smith KJ, Germain M, Yeager J, Skelton $H$. Topical $5 \%$ imiquimod for the therapy of actinic cheilitis. J Am Acad Dermatol. 2002;47: 497-501.

14. Sotiriou E, Lallas A, Goussi C, Apalla Z, Trigoni $A$, Chovarda $E$ et al. Sequential use of photodynamic therapy and imiquimod 5\% cream for the treatment of actinic cheilitis: a 12month follow-up study. $\mathrm{Br} J$ Dermatol. 2011; 165:888-92.

15. Rinne D, Linhart C, Schöfer H. Lip papillomatosis in immunodeficiency: therapy with imiquimod. $\mathrm{Br} J$ Dermatol. 2000;142: 196-97.

16. Marks R, Gebauer K, Shumack S, Amies M, Bryden J, Fox TL et al. Imiquimod 5\% cream in the treatment of superficial basal cell carcinoma: results of a multicenter 6-week dose-response trial. J Am Acad Dermatol. 2001;44:807-13.

17. Aldara [package insert]. Loughborough, England: 3M Health Care Limited, 2007.

18. Allam JP, Erdsach T, Wenghoefer M, Bieber T, Appel TR, Novak N. Successful treatment of extensive human papillomavirus-associated oral leucoplakia with imiquimod. Br J Dermatol. 2008;158:644-46.

19. Gencoglan G, İnanir I, Sahin O, Gunduz K. Imiquimod 5\% cream for isolated lichen planus of the lip. J Dermatolog Treat. 2011;22:55-9.

20. Brown RS, Farquharson AA. A topical imiquimod-induced oral mucosal lichenoid reaction: A case report. J Am Dent Assoc. 2014;145:1141-45.

21.Cantisani C, Lazic T, Richetta AG, Clerico R, Mattozzi C, Calvieri S. Imiquimod 5\% cream use in dermatology, side effects and recent patents. Recent Pat Inflamm Allergy Drug Discov. 2012;6:65-9.

22. Ermertcan AT, Gencoglan G, Eskiizmir G, Temiz P. Microinvasive squamous cell carcinoma arising in discoid lupus erythematosus lesions successfully treated with imiquimod 5\% cream. Indian J Dermatol Venereol Leprol. 2013;79:115-17. 


\section{CONFLICTS OF INTERESTS}

The authors declare no conflicts of interests.

CORRESPONDING AUTHOR

\section{Anne Diolina Araújo Morais}

Federal University of Ceará Campus Sobral (UFC)

Campus Sobral,

62010-560 Sobral - CE, Brazil

E-mail: annemorais85@gmail.com

25. Yasar S, Mansur AT, Serdar ZA, Goktay F, Aslan C. Treatment of focal epithelial hyperplasia with topical imiquimod: report of three cases. Pediatr Dermatol. 2009;26:465-68.

26. Wenzel K, Saka B, Zimmermann R, Gundlach $\mathrm{KKH}$, Barten M, Gross G. Malignant conversion of florid oral and labial papillomatosis during Accepted 18/07/2021 topical immunotherapy with imiquimod. Med Microbiol Immunol. 2003;192:161-64.

27. Wooten JM. Imiquimod. South Med J. 2005;98: 852.

28. Monteiro JSC, Susana CPSO, Júnior JAR, Gurgel CAS, Souza SCOM, Pinheiro ALB et al. Effects of imiquimod and low-intensity laser $(\lambda 660 \mathrm{~nm})$ in chemically induced oral carcinomas in hamster buccal pouch mucosa. Lasers Med Sci. 2013;28:1017-24.

29. Ganjian S, Ourian AJ, Shamtoub G, Wu JJ, Murase JE. Off-label indications for imiquimod. Dermatol Online J. 2009;15:4.

30.Pancevski G, Pepic S, Idoska S, Tofoski G, Nikolovska S. Topical Imiquimod $5 \%$ as a Treatment Option in Solitary Facial Keratoacanthoma. Open Access Maced J Med Sci. 2018;6:531-35. 